\title{
Ornamental Characteristics of the Musical Texture (through the example of pianoforte miniatures by A.K. Lyadov)
}

\author{
Natalia V. Vinokurova and Marina S. Shkolina* \\ Krasnoyarsk State Institute of Art \\ 22 Lenin, Krasnoyarsk, 660049, Russia
}

Received 02.11.2015, received in revised form 18.11.2015, accepted 26.12.2015

The author analyzes the musical texture of pianoforte miniatures written by the Russian composer, A.K. Lyadov: "Prelude" op. 42 no. 2 H-dur, "Prelude" op. 27 no. 2 H-dur, "Prelude" op. 11 no. 1 h-mol, "Birulki" op.2, piece no.1, aiming at finding the elements of ornamental compositions. The sympathy in compositional methods of musical texture and ornaments, their graphical similarity once again prove universal features of the language means of the art and synthetism of the composer's artistic thinking. This very type of thinking appeared to be of the most immediate interest by the representatives of the Russian artistic culture in the Silver Age. This work is conducted under the studies of extrapolation of the principle of plastic arts into the music.

Keywords: ornament, composition, synthesis, rapport, stroke, flourish, motive, Art Nouveau, ornamental method, A.K. Lyadov, prelude.

DOI: 10.17516/1997-1370-2016-9-1-150-157.

Research area: culture studies.

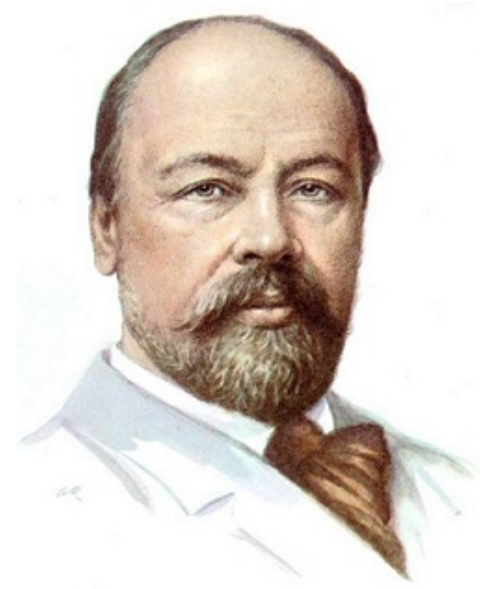

A.K. Lyadov (1855-1914)

At the turn of the $20^{\text {th }}$ century the Russian was marked with an intensive search for new language means of expression in different arts. ${ }^{1}$ Thus, a great significance was attached to an ornament as a multidimensional phenomenon, performing its artistic, aesthetic, symbolic, styling, dramaturgical, and, sometimes even psychological functions. These features explain such a great attention to the ornament and its wide acceptance in applied and decorative arts, architecture, painting and book graphics. In that sense, artistic characteristics of ornaments were taken on board by the representatives of one of

(C) Siberian Federal University. All rights reserved

* Corresponding author E-mail address: Nataly-pit@mail.ru,krasnoyarsk-asp@mail.ru 
the most prominent Russian art movement of that time, World of Art, (rus. - Mir Iskusstva) miriskusniki. Their turn to the ornamental methods in the texture and composition under the Art-Nouveau style in Russia at the turn of the $20^{\text {th }}$ century was taken off as a result of their interest to the Russian national heritage. In that context, it is necessary to mention works by an outstanding Russian composer, A.K. Glazunov, "who places emphasis on the technique of artistic ornamenting of the melody line in the sound-building" (Vinokurova, 2011: 32). This feature was bound to draw Lyadov's attention, concerning his respect and devotion to the national folk art. Quite likely, that all these factors have determined the creation of specific patterns of ornamental composition in his music.

Such a "contact" may well be found in the means of musical expression, in compositional schemes, dramaturgical methods, scaled-thematic structures and also in special aspects of metrorhythmic patterns.

One of the probable ways which identify that ornamental and artistic principle in music is the revealing of common features between language means of these two arts, i.e. music and ornamental composition. Most generally it can be described in the following way:

\begin{tabular}{|l|l|}
\hline \multicolumn{1}{|c|}{ Music } & Ornament \\
\hline Sound (tone) & Point \\
\hline Melody line & Line \\
\hline Motive (melodic idiom) & Motive \\
\hline Rhythm & Rhythm \\
\hline Texture (phonetic side), dynamics & Plastic \\
\hline Tone colour & Colour \\
\hline $\begin{array}{l}\text { Composition, texture (functional } \\
\text { side) }\end{array}$ & Composition \\
\hline Dynamics, tempo & Dynamics \\
\hline
\end{tabular}

Lets us also remark here on the number of compositional characteristics that are common for these two spheres: $\checkmark$ symmetry laws (the law of the balance of proportions, parts and the entire);

$\checkmark$ law of statics and dynamics (quiescent and dynamic states);

$\checkmark$ law of rhythm (regular interchange of major and minor parts);

$\checkmark$ laws of identity (identity is an essential constitutive principle in music, applied and decorative arts and architecture).

Moreover, there are some principles in the structure of musical and ornamental compositions which can be considered as similar:

\begin{tabular}{|l|l|}
\hline \multicolumn{1}{|c|}{$\begin{array}{c}\text { Ornamental } \\
\text { composition }\end{array}$} & Musical composition \\
\hline $\begin{array}{l}\text { Principle of } \\
\text { proportionality }\end{array}$ & $\begin{array}{l}\text { Ratio of sections and } \\
\text { parts of the form }\end{array}$ \\
\hline $\begin{array}{l}\text { Principle of hierarchy } \\
\text { (the law of the } \\
\text { dominant) }\end{array}$ & $\begin{array}{l}\text { Laws of the rhythmic } \\
\text { ratio, key points }\end{array}$ \\
\hline $\begin{array}{l}\text { Principle of ornamental } \\
\text { counterpoint }\end{array}$ & $\begin{array}{l}\text { Methods of the theme } \\
\text { material development } \\
\text { (for example, } \\
\text { polyphonic one). }\end{array}$ \\
\hline Method of contrast & $\begin{array}{l}\text { Dynamic plan of } \\
\text { the theme material } \\
\text { development, tempo } \\
\text { ratio, rhythm, } \\
\text { articulation methods. }\end{array}$ \\
\hline
\end{tabular}

In visual arts a stroke is, on the one hand, one of the graphical elements, and on the otherone of its techniques. The stroke in painting is made by a short movement of one's hand with a brush (or, a pencil, pen or etc.). In ornaments, strokes can be analyzed as a motive for rapport schemes. It is to be recalled, that a rapport (fr. rapport <- rapporter - "to bring back") is one of the basic ornamental elements or a repeated part of the figure. Here, its aesthetic characteristics are most significantly appeared; the expression side is demonstrated by the way of its application (accuracy, easiness and etc.), line-weight and other things. In visual arts, representation of 
the volume and dynamics in composition and form recognition are also one of the functions performed by the stroke.

Lets analyze the pattern of "Prelude" Op. 42 no.2 H-dur. Focusing on the specific aspects of the way how the ornamental composition can be built, for our purpose, in the function of motive in the rapport structure the first rhythmic figure, resembling, thanks to the dash rhythm, a short stroke, can be described (Fig. 1).

The whole music piece is built on the distinctive dynamics of that motive, so as it allows saying about a unique rapport net (the principle of repeated elements).

In this case, a "wave-like" movement, expressed by the change in the motives direction in the phrase (rising in the beginning (b. 1,2) and further falling (b. 3, 4), also stressed by the sound reinforcement or reduction (cresc. - dim). Besides, a counter-movement inside the motive (including sounds of all the voices), gives an initial impulse to the range expansion. The detail cresc., in its turn, implies a more rich and colourful speech of the motives (probably, in visual arts it can be more heavy or full stroke).

In the third part the general movement "smoothing" little by little, but the feeling of the volume is still here due to introducing of the lowercase, as well as pauses and larger values (quarters) that support some "exhaustion" of the space (b. 18-20) (Fig. 2):

Thus, figuratively speaking, the ornamental rapport method used in the piece; the dynamics of movements, created through the rhythm of motives, similar in their form, but different in the range; the expressiveness of the stroke on the back of the waviness of the dynamic development encourage a music image transfer (a bright, delightful and joyful mood), the nature of which has already been mentioned in the stage direction - Grazioso.
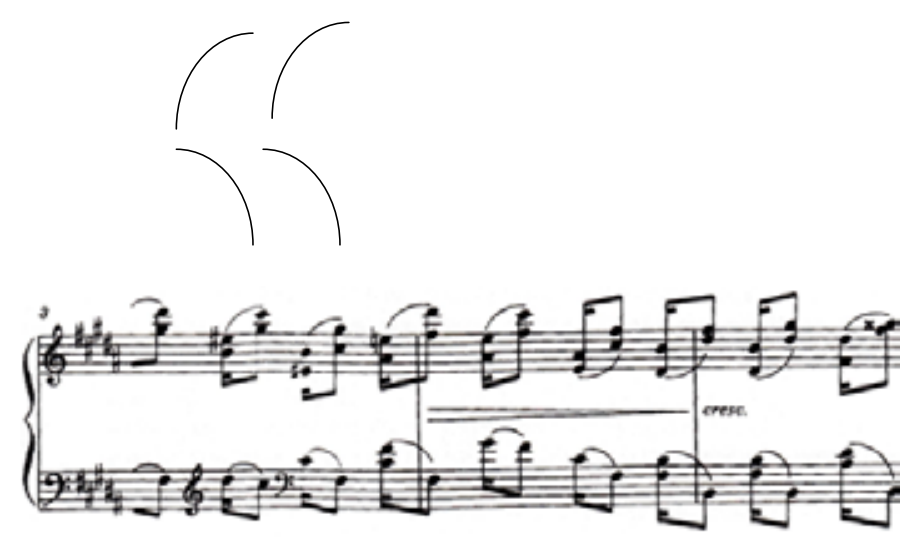

Fig. 1

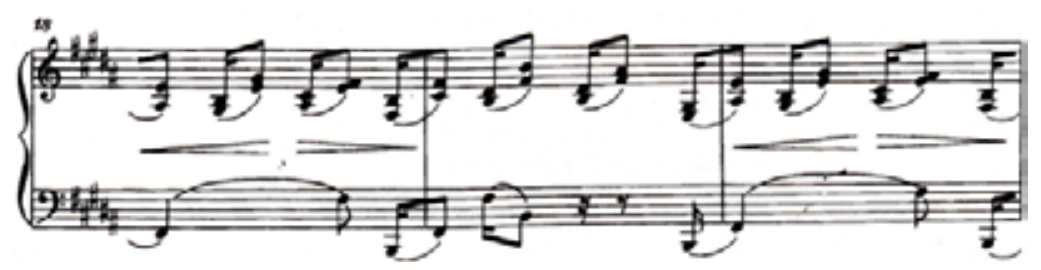

Fig. 2 
Another example of such composition peculiar to the ornament is "Prelude" Op. 27 no

\section{H-dur.}

In this context, the motive structure is also subjected to the repetition (rapport). As being a motive, a figure comprised of five quavers, by their contouring similar to one of the techniques of plotting lines in graphics, i.e. a flourish (Fig. 3).

The accompaniment part is developed by way of quarter note triplets the dynamics of which visually resembles a zigzag (b. 4, 5) (Fig. 4).

Perhaps, in this case we may say about some kind of "ornamental counterpoint" (V.M. Shugaev), in which the complexity of the rhythm can be achieved by the rhythmical series interfering. Thus, a polyrhythmic combination with an upper voice (5:3) in Presto makes transferring of the music patterns: emotional uplift, excitement).

In the third part, the motive of the upper voice are organized "in pairs" (by focusing on the first sounds) and different in the pitch with the tendency of rising (h-h, c-c, h-h, c-c and etc.), as, probably, by the analogy with a vertical shear in ornaments. There is an element of an organ section appears, - in two times (b. 31, 33, 35) in the beginning and then, more intensively, on each pulsation (b. 31-40) (Fig. 5).

If we consider repeating of the V-step as a set of points in the ornament, placed in a certain manner (the point in the ornament may be used for the volume and space development of some forms), so a tendency towards the range expansion can be seen (almost four octaves). The
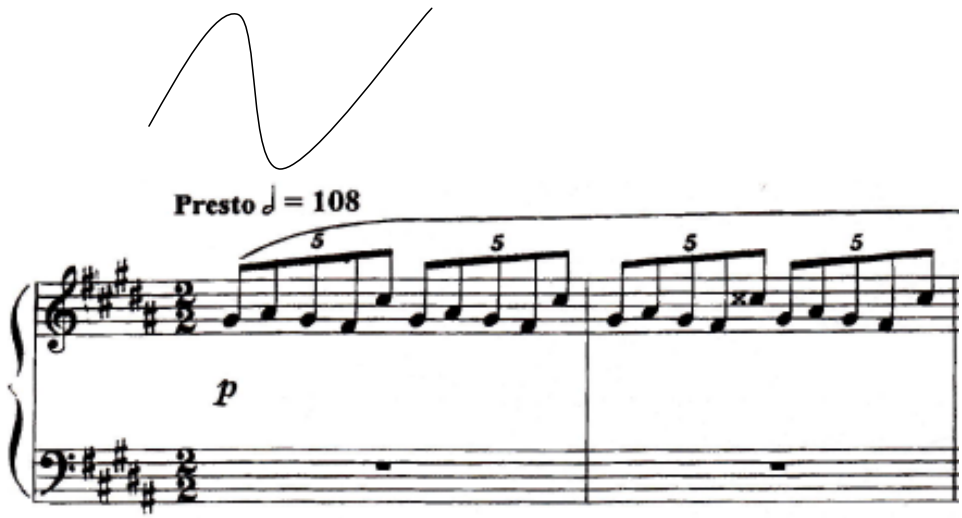

Fig. 3

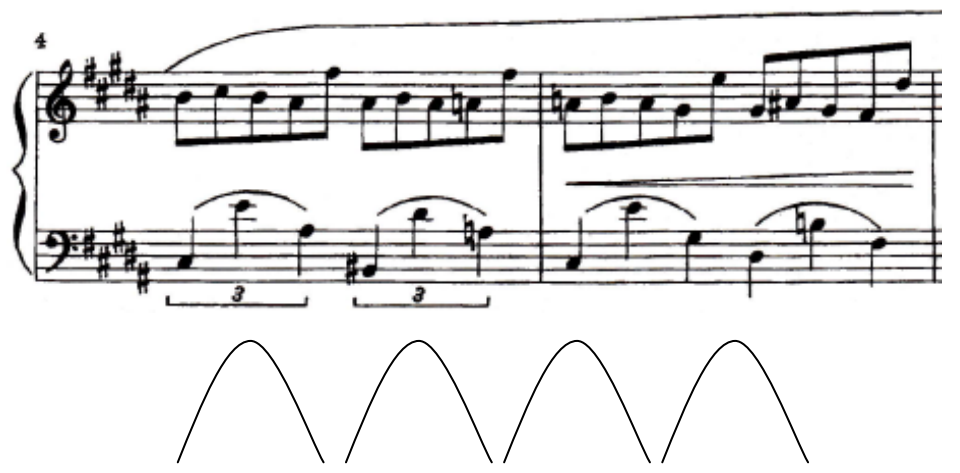

Fig. 4 
range expansion is supported by the dynamic sound reinforcement (cresc.), and, consequently, a certain form-building function performed by the element of the organ part can be defined (preparing of the key moment in t. 45).

As the following example we will consider the piece no. 1 from the series "Birulki" op.2. Birulki are small wooden toys (sometimes they were made of ivory), played both by adults and children. From a trickle of such toys players by turns should hook and take one toy, so as that trickle stands the same. In the time, when A.K. Lyadov created "Birulki", the artistic activity of the Abramtsevkii's group representatives and, in particular, works by Elena Polenova (1850-1898), gained a rapid growth and importance. The beauty of the smallest figures, riches in details add to many of her works made in the genre of miniature, a toy-like look and demonstrate a masterful performance in the fine techniques. Perhaps, artistic searches of E. Polenova came closely to A.K. Lyadov's ones.
The first miniature of the series was written in a simple three-part form. The organ part method, which can be explained in this case as an element of the ornament is the peculiarity of the texture development of the accompaniment . Its very functional mission is focused on the extreme part formatting (the first and the third one), based on the use of one of the graphic elements - a point. Apparently, the sound "do" repeated on the whole length of the part possesses not only a visual character, but also performs a particular form-building function. An original rhythmic structure lies in the distribution of the even interchange of upper and lower sounds in the context of the triple meter (3:4), creating a certain shift of accent points (b. 1-4) (Fig. 6).

On the other hand, if we draw our attention to the picture of the organ part, we will see that the distribution on its two times length corresponds with the phrasing of the melody line (the melody is based on the progression (sequence), each detail of which is consisted of a four-sound motive and repeated 2.5 times) (b. 7, 8) (Fig. 7).
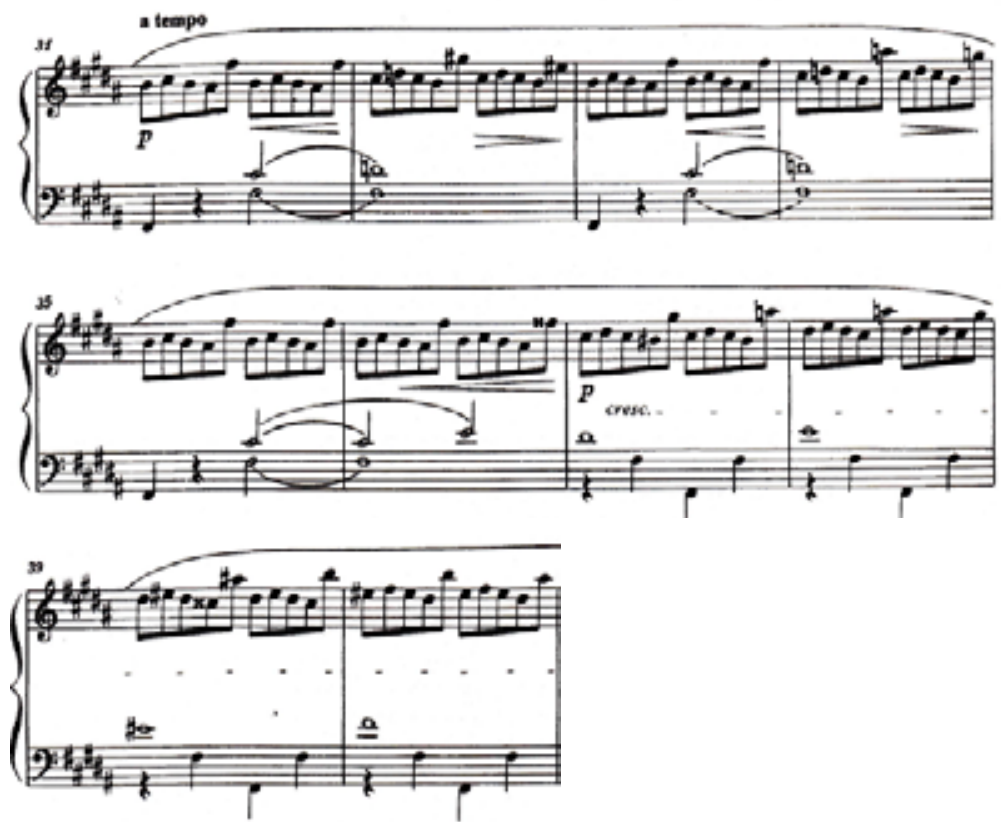

Fig. 5 


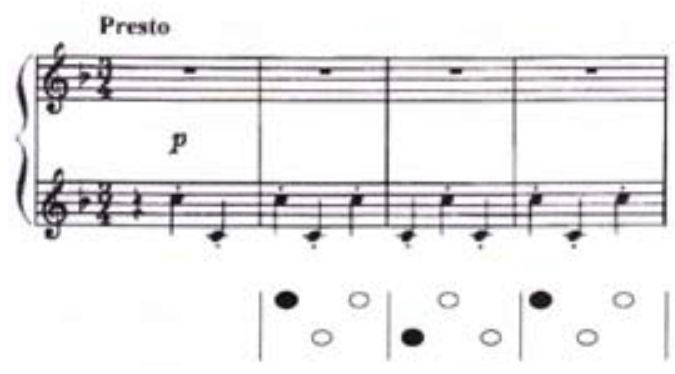

Fig. 6

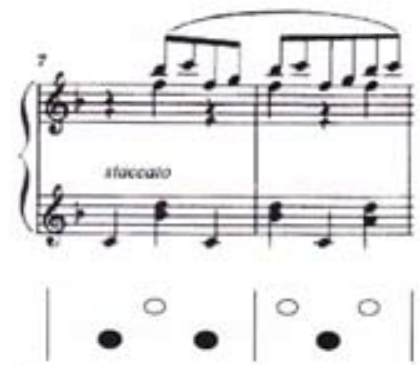

Fig. 7

Thus, there is a feeling of some kind of a play of strong and weak beats, and the accents shift, in its turn, contributes to a certain improvisation of the rhythmic picture, reflecting a playing beginning of the piece.

The subject basis of "Prelude"Op.11 no 1 B-minor is a melody of the Russian folk lyrical song "Those, in the Life, too hard..." (rus. - "I chto na svete prezhestokom") form the songbook by M. Balakirev (No. 33, edited in 1957 by E. Gippius). The form of the piece is close to the strophic one (i.e. peculiar for vocal songs); it is quite proportional: there are 2 bars (introduction) +38 bars +38 bars. In this sense, the compositional structure matches the symmetry law, that is frequently used in the ornamental art.

The way of how the accompaniment can act is also compared with the ornament: the interchange of two intervals in a triplet rhythm, on the one hand, creates a waving movement (visually, a similarity to a zizag-like element implied in the basis of the ornament can be seen), based on the rhythmic repetition of the motive (that is in the same way corresponds with the principle of the ornamental structures) together with symmetric elements. Speaking about the components order, we conclude that there is a method of rotation, peculiar to the ornament (b. 1,2) (Fig. 8).

On the other hand, there are some combinations of horizontal "punctual" development of the repeated notes (a point as a structural element of the form-building in the ornament) (ib.) (Fig. 9).

Conspicuous is a compositional decision for the space by the means of manipulation on the volume of the texture. It is shown through a gradual range expansion due to introducing a separate bass-line, octave doubling of the melody (b. 23-30), reinforcement of the dynamic sound $\mathrm{p}-\mathrm{f}$ (b. 11-24), and, further, to some "closure" of the movement range through two monothematic melodic passages: falling in the beginning (b. 3134), and rising (b. 31-40), which create a kind of an 


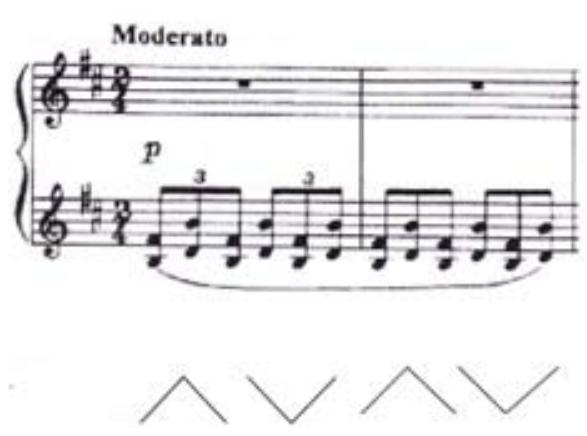

Fig. 8

arch, uniting great texture layers. The structure of these passages is also based on the conventional repetition of two melodic motives (the method of integration in the ornament), plastically quite expressive.

A bright, delightful and free nature of the music is possessed in "Prelude" op. 13 no. 3 A-dur. The texture of that music piece is presented as doubled notes on the back of figurative accompaniment (wide skips are used). The melodic line of the middle voice is based on the motives composed of repeated sounds (e-e-e-e-e-e-d-d-ch-f-g; e-e-e-d-c-c-c-c and etc.). The entrance at the two eight of the bar (a weak beat), a pass of the bass to the third beat with the period of one measure (b. 2, 4, 6...) support creation of the syncopating rhythm. Thanks to this, the nature of the music is characterized by a reverence and excitement; the dynamics of these 16 notes surrounding the middle melodic voice, resembles circular (or wavelike) figures, completing the effect of "flight" or "spinning" (b. 1) (Fig. 10).

The principle of notes repetition resembling certain points, a combination of which may well create a particular point picture, can be considered as another ornamental method. An accurate paired group of sounds in the part of accompaniment (i.e. two thirds +two sixth). Thus, the presence of three layers, i.e. the bass line (as a rule, which is based on the organ bass, especially in the second part of the prelude), the middle

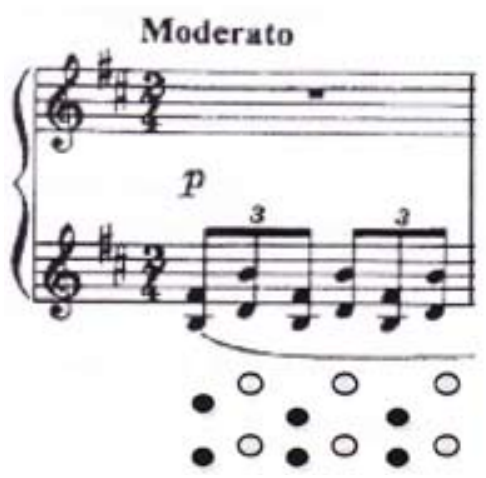

Fig. 9

melodic voice (based on the repeated sounds) and accompaniment part (as a gorgeous picture made of doubled notes), in their combination give us a kind of an ornamental composition, built on the principle of the "ornamental counterpoint". The sharp halving of the form (20 bars +23 bars), a square structure of schemes, relevant to compositional laws of the ornament, balance the inner reverence of the rhythmic picture of the music piece.

Probably, Lyadov's taste for aestheticization, or, idealization, to some extent, of life events in this piece appears due to the creation of a "picture" of a suffering girl, experiencing deep feelings ( this fact is encouraged by the texture modifications, expressing the depth of the emotional state). At the same time the picture is like bordered of the "ornamental band". This band, in its turn, possesses a symbol of water, manifesting as waving "waggle" of triplet in the accompaniment and containing the idea of purification, peace and freedom of the time burden. Thus, there is an effect of a contemplation for the feeling, sincerity, chastity and straight emotions. The principle of ornamentation in this very case provides the symbolic image of water implementation (the motive of water), the psychological state passing, and in doing so, reviling certain nuances of the author's things about the ideal as an citadel of the spirit purity, beauty and harmony. 
In such a manner, the discovering of principle of the plastic arts (i.e. visual, applied and decorative arts) in the musical works by A.K. Lyadov, may become a ground for the so called synthetism of his artistic thinking. Despite of staying in the frames of favourite genres and forms, this prominent Russian composer was eager to widen the sphere of images, achieve an extreme expression of each of the elements of the music language through the means of expression in neighbouring arts.

\title{
References
}

Vinokurova N.V. Simfonicheskoe tvorchestvo A.K. Glazunova: na puti $k$ neoklassitsismu [Glazunov's Symphonies: on His Way to Neoclassicism]. Krasnoiarsk. 2011. 215 p.

Gasheva N.N. Dialog literaturi i filosofii v prostransnve russkoi kul'tury XIX-XX vekov // Voprosy kul'turologii [The Dialog between Literature and Philosophy in the Space of the Russian Culture of the 19-20 Centuries // The Culturology Issues.]. 2011. (3). pp. 54-59.

Lapshina N.P. Mir iskusstva. Ocherki istorii i tvorcheskoi praktiki. [The World of Art. Outlines of the history and Artistic Practice]. M.1975. 287 p.

Sarabianov D.V. Stil' modern [Art Nouveau]. M. 1989. 293 p.

Florencki P. Analiz prostranstvennosti $i$ vremeni $v$ khudozhestvenno-isobrasitel'nykh proisvedeniiakh [Analysis of spaciousness and time in pictorial artworks]. M. 1993. 324 p.

\section{Орнаментальные свойства музыкальной фактуры (на примере фортепианных миниатюр А.К. Лядова)}

\author{
Н.В. Винокурова, М.С. Школина \\ Красноярский государственный институт искусств \\ Россия, 660049, Красноярск, Ленина, 22
}

\begin{abstract}
В статье рассматривается музыкальная фактура фортепианных миниатюр русского композитора А.К. Лядова - «Прелюдии» соч. 42 № 2 H-dur, «Прелюдии» соч.27 № 2 H-dur, «Прелюдии» соч.11 № 1 h-mol «Бирюльки» ор.2, пьеса № 1 с точки зрения выявления в ней приемов орнаментальной композищии. Обнаружение общности композиционных приемов музыкальной фактуры и орнамента, графического сходства между ними выступает свидетельством известного универсализма языковых средств искусства, а также синтетизма лядовского композиторского мышления. Именно такой тип мылиления оказался чрезвычайно востребованным представителями русской художественной культуры Серебряного века. Данная работа выполнена в рамках исследования экстраполяции в музыку принципов пластических искусств.
\end{abstract}

Ключевые слова: орнамент, композиция, синтез, раппорт, итрих, росчерк, мотив, модерн, орнаментальный прием, А.К. Лядов, прелюдия.

Научная специальность: 24.00.00 - культурология. 